\title{
Family Social Reproduction: Conflict and Compromise in Cross-Border Marriages between Chinese Malaysian Men and Vietnamese Women
}

\author{
Chee Heng Leng ${ }^{\mathrm{a}}$ and Brenda S.A. Yeoh ${ }^{\mathrm{b}}$
}

\begin{abstract}
In this paper, we use the framework of family social reproduction to investigate care relationships within cross-border marriages in Malaysia. Examining the narratives of Chinese Malaysian men and their Vietnamese spouses, we find that (i) the Malaysian men's labour migration during their twenties and thirties leads to the deferment as well as enablement of marriage, reconfiguring social reproduction temporally and spatially within their life courses, while (ii) the Vietnamese women's aspirations for migration, work, and marriage interlink with their desire to seek a better life, and their motivations to secure better options to contribute to the social reproduction of their natal families. Tensions in cross-border marriage arise from unmet expectations of care and sustenance, leading to frictions over contested roles and responsibilities in daily household maintenance and care activities, and compromises as marriage partners formulate social reproductive strategies. Exchanges of care, reproductive labour, and money within these marriages are embedded in relational meanings, pointing to the significance of recognising that the care work that shapes and sustains marital relationships is bidirectional, reciprocal, and undertaken by husbands as much as wives.
\end{abstract}

Keywords: Family social reproduction; Cross-border marriages; Care relationships; Vietnamese marriage migrants; Chinese Malaysian men.

JEL Classification: J120, J100, J190

a Independent scholar. Halaman Khoo Cheow Teong, George Town, Penang 10100, Malaysia. Email: cheehengleng@gmail.com, ORCID: 0000-0001-6731-8724

b Corresponding author. Department of Geography and Asia Research Institute, National University of Singapore, AS8 Level 7, 10 Kent Ridge Crescent, Singapore 119260. Email: geoysa@nus.edu.sg, ORCID: 0000-0002-0240-3175 


\section{Introduction}

The rapid rise in cross-border marriages between East and Southeast Asian countries in the last few decades is largely due to the increasing phenomenon of women from the region's poorer countries crossing borders to marry men in the wealthier economies. Beginning from the mid-1980s, men from South Korea, Taiwan, Japan, and Singapore married women from China, Vietnam, the Philippines, and Indonesia in increasing numbers (Jones, 2012; Bélanger, 2010). This increase has been partly attributed to the role of commercial agencies that match men who are disadvantaged in local 'marriage markets' to women who wish to migrate in the hope of a better life (Jones, 2012).

Cross-border marriages are symptomatic of the broader trend where social reproduction is no longer confined within the nation-state but increasingly takes place transnationally (Douglass, 2006; Lee,2012; Yeoh et al., 2013; Yeoh et al., 2014). On the one hand, individuals, families, and households face increasing difficulties meeting livelihood and reproductive needs in neoliberal economies with inadequate state support for social security, childcare, education, health care, and elderly care. On the other hand, globalising trends and uneven economic development create opportunities for international migration for work, education, retirement, and marriage, resulting in a diverse range of transnational strategies for family formation and sustenance. A family member therefore may migrate to work abroad in order to generate remittances, children may be sent abroad for schooling as a cultural capital accumulation strategy to enhance their competitive advantage, and retirees may migrate to a lower income country in order to stretch their pensions. Set within this larger context, cross-border marriages are householding strategies allowing East and Southeast Asian men and women to overcome constraints within their own national territories in order to achieve what may be considered better options for family formation and household maintenance. Although less well documented, these strategies have also been identified among Chinese Malaysian men who marry Vietnamese women (Chee et al., 2012).

In this paper, we examine the case of commercially-mediated crossborder marriages between Vietnamese women and Chinese Malaysian men through the overarching frame of social reproduction. While social reproduction is broadly understood to refer to the reproduction of society at the level of social institutions, culture, polity, and economy, we follow 
Locke et al. (2013) in training the analytical lens on the level of families and households, giving attention to biological, everyday, and intergenerational reproduction. In this sense, social reproduction encompasses decisions, strategies, and practices that foster, and shape social relations connected to partnering, forming households, having and raising children, daily household maintenance, and elderly care. Douglass (2006: 421) uses the term 'global householding' to highlight the significance of transnational dynamics in the 'continuous process of social reproduction that covers all life-cycle stages and extends beyond the family.' In this paper, however, we focus less on the transnational relationships and activities that sustain householding for marriage migrants and instead shift attention to men's and women's motivations and agency in contracting cross-border marriages, and how they subsequently work to develop and sustain fragile new relationships with their partners and marital families.

In the next section, we provide a review of the extant literature on social reproduction and cross-border marriage, with a focus on Vietnamese marriage migration in East and Southeast Asia. This is followed by an overview of the social reproductive issues faced by the Chinese Malaysian population. A brief section on our research methods follows before we turn attention to three themes in our study. First, we draw from the narratives of the Malaysian men to show how their experience of delayed marriage and desire for companionship, intimacy, and care are interlocked with their own previous work migration histories. Second, from the Vietnamese women's narratives, we show how their motivations and aspirations for migration, work, and marriage interlink with their desire to seek a better life, and to help their own natal families. Third, we use both husbands' and wives' narratives to illustrate the tensions that arise from unmet expectations of care and sustenance, the frictions over contested roles and responsibilities in daily household maintenance and care activities, and the compromises that marriage partners arrive at in formulating social reproductive strategies. Finally, highlighting how our Malaysian case study_offering a different context from the more common focus on East Asia and Singaporecontributes to the literature, we then draw some concluding observations.

\section{Social Reproduction and Cross-Border Marriage}

Social reproduction in political economy has been defined primarily 
in relation to capitalist production, referring to the reproduction of the labour force, and the perpetuation of modes of production and structures of class inequalities in society (Laslett and Brenner, 1989; Winders and Smith, 2018). In seeking to locate the roots of women's subordination and gender inequality, this conceptualisation was considerably broadened in subsequent feminist literature to encompass all work that goes into the daily maintenance of existing life as well as reproducing the next generation, involving relations of care, family, and community (Laslett and Brenner, 1989; Winders and Smith, 2018). Although the provisioning of society's daily and generational needs may be met in various ways-for example, through state agencies, commercial businesses, or non-profit organisationsin reality, it is primarily provided within the household by women's hidden and unpaid labour that is organised within a set of social relationships predicated on gender inequality (Laslett and Brenner, 1989).

In a comprehensive review, Winders and Smith (2018) analyse how feminist literatures on social reproduction develop historically in step with the societal changes that they seek to elucidate. In contemporary globalisation, increasingly entrenched neoliberal capitalist logics have led to the uneven proliferation of production sites across countries, as well as the unmooring of sites of production from reproductive sites. It is in this context that increasing migration, particularly given the feminisation of migration for care labour, has led to a burgeoning of the literature on transnational care work (Hochschild, 2000; Yeates, 2004; Isaksen et al., 2008). These works centre the social relations and care work associated with social reproduction, thereby making visible the linkages between the multiple sites of production and social reproduction through transnational practices, and 'demonstrating how global processes become embodied, intimate, and literally "close to home" (Winders and Smith, 2018: 10, 14). The concept of 'global care chains' for example highlights the international transfers of reproductive labour from the employer to the migrant domestic worker in the host country, and from the migrant domestic worker to her substitute carer for her children who are left behind in the home country (Hochschild, 2000; Lan, 2008).

Marriage migrants are situated in a similar structural position to care labour migrants in that they are also recruited to provide reproductive labour (Lan, 2008). While care labour migrants providing reproductive labour in institutional settings (as nurses and caregivers) and homes (as domestic workers) are paid, marriage migrants provide unpaid reproductive 
labour as wives, mothers, and daughters-in-law (Lan, 2008). Reproductive labour includes not only the physical labour in caring for children and the elderly and household maintenance (cooking, cleaning, laundering, shopping), but also biological reproduction, as well as the emotional and social aspects of care, such as socialising children, providing emotional support, and maintaining kin and community ties (Lan, 2008). Incorporated into families as unpaid reproductive workers, the relations and meaning of 'family' for marriage migrants can be double-edged. On the one hand, the marital family can be a site of exploitation; on the other hand, the family is also 'an important source of care provision for the migrant and may be generative of meanings and relations of intimacy that confer well-being' (Yeoh et al., 2013: 1938). Focusing on negotiations of intimate care labour within commercially-mediated cross-border marriages in Singapore, Yeoh et al. (2014: 285) observe that the meanings of specific acts of care-from companionship to cooking-depend on the relational context in which they are performed and that the perceived quality of care tended to be used as a barometer for love. They also argue that 'the monetisation of the care relationship in commercially-arranged international marriage does not necessarily make it less sustainable or more fragile; instead, it may help to balance the relationship when there is major asymmetry in the care relationship (money and remittances provided by the husband can be read favourably as currency for exchange in return for the wife's care labour)' (Yeoh et al., 2014: 290). Likewise, Lu's (2012) study of Taiwanese veteran soldiers who marry mainland Chinese spouses in Taiwan found that the majority of veterans consider their marriage to be an exchange, promising long-term material security to their wives and family members in return for care. Like Yeoh et al. (2014), Lu stresses that this is not a simple exchange of one item for the other, but involves reciprocal caregiving and care receiving that are embedded in cultivating relationships that require 'investment of both economic and affective resources' (Lu, 2012: 235).

At the level of nation-states, it has been argued that in wealthy economies such as Singapore, Taiwan, and Korea, the cross-border marriages between local men and women of poorer countries such as Vietnam is a response to a crisis in social reproduction (Yeoh et al., 2013; Lan, 2008; Lee, 2012). Lee (2012), for example, explains that in Korea, rapid economic development and urban industrialisation in the 1960s led to increases in rural to urban migration, which coupled with rising women's labour force 
participation and education to create a shortage of brides in rural areas in the late 1980s. Cross-border marriages initially emerged as a solution to this rural crisis, and later spread to the urban working classes after the late 1990s due to governmental policies of neoliberal restructuring that retrenched welfare. Likewise, in Singapore, cross-border marriage has been considered a class-specific solution to Singapore's reproductive crisis, in which older, working-class men with lower education are marginalised in the local 'marriage market' (Yeoh et al., 2013). While middle-class families can afford to employ migrant domestic workers to provide paid reproductive labour, working-class families incorporate migrant wives to provide unpaid reproductive work. The crux of the 'reproductive crisis' in these countries lies with working-class men who cannot find local wives due to their relative poverty, low education, and rural domicile. In these patrilineal societies, men feel the pressure to marry in order to provide daily household reproduction and intergenerational care for elderly parents, and to continue paternal lineages, while their female counterparts refuse to accept traditional wifely roles (Bélanger, 2010; Lan, 2008; Yeoh et al., 2013). Filling in this demand, women from lower-income countries engage in marriage migration to higherincome countries with the objectives of securing a better life for themselves, and of improving their natal families' standard of living through remittances.

In the receiving societies, cross-border marriage serves to sustain household social reproduction in a system where social reproduction, welfare, and care provisioning are largely privatised and located within the familial realm. Some authorities such as the local and national governments in Japan, South Korea, and Taiwan recognise the importance of marriage migrants' role in household social reproduction, enacting policies to help male citizens meet women from Southeast Asia and China (Piper and Lee, 2016). Nevertheless, other policies constricting pathways to citizenship and restricting rights to residency and employment are also widely encountered in the region (Cheng, 2013; Yeoh et al., 2013; Yeoh et al., 2021). State barriers to marriage migrants' employment and income generation activities impinge on household survival strategies both for their natal as well as marital families. As their husbands' incomes are often stretched, marriage migrants find it difficult to ask for money to remit back to their natal families, jeopardising one of their original objectives in engaging in crossborder marriage. Scholars have thus argued that the insertion of marriage migrants into household social reproduction in these restrictive contexts 
further reinforces gender norms, and entrenches structural class and gender inequalities in receiving country contexts (Lee, 2012).

In this paper, we expand on the discussion above through our study of commercially-mediated marriages between Chinese Malaysian men and Vietnamese women. Using the lens of social reproduction, we investigate the motivations and subject positions of the men and women who engage in these marriages. How do the men express their aspirations to secure reproductive labour and care, and how do they negotiate these vis-à-vis their spouses' expectations? What are the Vietnamese women's aspirations and how do they navigate their new family circumstances and structural constraints to achieve these aspirations? We draw from the narratives of our interviewees to elucidate the shifting dynamics in the relations and practices of reproductive labour and care as the marriage migrants and their spouses steer through conflicts and compromises.

\section{Chinese Malaysians' Social Reproductive Crisis}

In 2010, Chinese Malaysians, as the second largest ethnic category after the majority Malays, constitute a quarter of the ethnically diverse population in the country (Department of Statistics Malaysia, 2011). ${ }^{1}$ Since the country's Independence in 1957, the proportion of Chinese in the population has steadily declined from $37 \%$ to $23 \%$ in 2020 , and is projected to fall below 20\% in 2040 (Department of Statistics Malaysia, 2016). The decline has been attributed in large part to a relatively faster rate of decline in fertility rates among the Chinese compared to the other ethnic groups. Since marriage is still the normative route to childbearing and family formation, the decline in fertility has in turn been traced to a long-term trend in men and women marrying at later ages, and increasing numbers remaining unmarried (Tey, 2011). Although this trend can be seen in all ethnic groups, it is particularly pronounced among the Chinese, where higher proportions of singlehood are experienced by men with lower education and women with higher education (Tey, 2011). In this regard, the pattern of delayed and non-marriage among Chinese Malaysians is similar to Singapore and East Asian countries (Jones et al., 2011: 5).

These declines in marriage and fertility rates accompany broad transformations in the country over the last five to six decades. In particular, increases in women's educational attainment and employment have expanded 
women's options, with other life options seriously contending with marriage. Rapid urbanisation, industrialisation, and globalisation have opened up opportunities for women who may favour an independent lifestyle that is more consonant with singlehood. With more women attaining higher levels of education, and the propensity for women towards hypergamy, this eventually results in a 'marriage squeeze' at both ends of the educational and socio-economic ladder, where women with higher education and men with lower education find themselves with lower chances of finding marital partners (Tey, 2011; Jones, 2012: 32).

The shrinking Chinese share in population and declining fertility and marriage are a source of anxiety among the 'Chinese community,' as expressed through the leaders of Chinese clans and Chinese-based associations. ${ }^{2}$ Some Chinese clan associations began offering monetary incentives for having children, and in 2001, a Chinese-based political party started an initiative in matchmaking. ${ }^{3}$ Ethnic differentials in population growth trends carry significant political implications in a national context where ethnicity is a major organizing principle for competitive resource allocation and redistribution. Since the inception of the New Economic Policy in 1970, ethnic boundaries have increasingly hardened as state policies that were earlier perceived as affirmative action policies favouring the Bumiputera become perceived as discriminatory against non-Bumiputera. Bumiputera, literally 'sons of the soil,' consists of majority Malays and the native populations of East Malaysia, and receives favourable treatment through ethnic quotas for a host of state provisions, including places in public universities, educational scholarships, and administrative positions (Koh, 2014).

The perception that Chinese Malaysians face a crisis of social reproduction is reinforced by large numbers of Chinese Malaysians emigrating to other countries, the majority to Singapore (Koh, 2014). While emigrants who are able to make a permanent move are usually the more highly educated or those with higher socio-economic status, the large numbers of working-class Chinese Malaysians who migrate to Singapore do so as transient foreign labour, eventually returning to Malaysia. There is also a significant phenomenon of Chinese Malaysians migrating to Japan, Taiwan, and the United Kingdom as undocumented labour, with most eventually returning. While these trends in population, fertility, marriage, and emigration may be of concern to Chinese Malaysians, they do not constitute 
issues that receive the attention of policymakers at the national level, unlike in other Asian countries.

This brief account of social reproduction issues among Chinese Malaysians provides a context for understanding the rise of commerciallymatched cross-border marriages among Chinese Malaysian men. Commercial matchmaking agencies for cross-border marriages made their appearance in Peninsular Malaysia in the early 2000s, and most were offshoots of agencies in Singapore (Chee et al., 2012). These agencies primarily match Chinese Malaysian men with Vietnamese women. Vietnamese women who enter the country are usually given one-month tourist visas, and during this time, the matchmaking agency will look for a match for them. A successfully matched couple will register their marriage quickly, and then proceed to apply for a short-term spousal social visit pass. According to the governmental news agency, marriages between Malaysian men and Vietnamese women increased from 28 in 2001 to 1,185 in $2005 .^{4}$ Nevertheless, Vietnamese women constituted less than $10 \%$ of foreign spouses of Chinese male heads of households in 2010, ranking numerically below Indonesians and Thais. ${ }^{5}$

\section{Study Methods}

This paper is part of a larger study investigating the conceptual categories of state boundaries, cultural politics, and gender negotiations in different types of international marriages in Malaysia and Singapore. For this paper, we focus on the narratives of Vietnamese women and Malaysian men who married through commercial brokers. Our study area is limited to the west coast of Peninsular Malaysia, focusing, though not exclusively, on a town near Kuala Lumpur, small towns, and Chinese new villages ${ }^{6}$ in the state of Perak, and a small town in the state of Melaka. Our fieldwork team consisted of three researchers (including the two authors), and two research assistants, one of whom spent the entire time in the field, while the others made extended field visits. Three team members are ethnically Chinese and can communicate in Mandarin, Cantonese, and Hokkien, while the other two are Vietnamese. Most of the fieldwork and interviews were carried out between March 2009 and February 2010, but we made return visits in April and August 2010 and January 2011.

The research is based on an ethnographic approach, where the aim is 
to uncover underlying logics that can explain human behaviour and social processes within the framework of social structures. Our research assistant stayed in a Chinese new village in Perak for prolonged periods during which time she identified couples and matchmakers and connected with them. She built upon these tentative connections through repeated social visits, which were reinforced by visits from other members of the team, in particular the Vietnamese researchers. We also identified commercial matchmaking agents through newspaper and internet advertisements, some of whom were themselves commercially-matched Vietnamese-Malaysian couples. In addition, we followed leads given by friends and snowballed from our initial contacts. While there were some who turned us down or avoided us with repeated excuses, many of those whom we met agreed to participate in our study. The open-ended interviews were guided by a set of themes that included family background, migration motivation and experience, matchmaking and marriage, family life, work, residency and citizenship, and aspirations for the future, and were conducted either in Mandarin, Cantonese, Hokkien, or Vietnamese, or a mix of languages. Most of the interviewees, especially the men, allowed their interviews to be recorded. For those who did not want to be recorded, we took notes during the interviews. All interviews were transcribed and translated into English. Pseudonyms are used to ensure anonymity, and ages and biographical information are in reference to the time of the interview.

In total, we collected 62 interviews from 25 couples, 7 wives, and 5 husbands. Six of the couples were also matchmaking agents. Our interviewees were not random individuals, many of them knew (or knew of) one another, constituting several loose clusters and networks. As such, our interactions with them also included social get-togethers that usually centred on cooking and eating Vietnamese dishes. Our researchers, therefore, have copious fieldnotes from these social events, focused particularly on the conversations among Vietnamese women. There are of course inherent biases in the method of convenience sampling that we used. We expect that those whose marriages were in an unstable or fragile state would decline participation, resulting in a bias toward generally successful marriages. Despite this caveat, we did interview a few couples who were unhappy with their marriages, including a couple that seemed to be heading irreversibly toward a breakdown. In any case, we did not specially look for divorced or separated individuals, although we were cognisant that there could be many, 
since a major theme in the discourse coming out from our fieldwork and from the media was that of 'runaway brides.'

\section{Delayed Marriage, Companionship, and Care}

The 30 husbands whom we interviewed were keenly aware that their marriages were delayed compared to normative practice. For the majority, who were mostly in their $40 \mathrm{~s}$ at the time of marriage, it was their first marriage. ${ }^{7}$ They attributed the delay to being poor when they were younger, which meant that they had to work very hard, sometimes migrate for work, enduring difficult living and working conditions overseas. In such circumstances, marriage was postponed or never became a possibility. A few had disappointing relationships with former girlfriends, and mostincluding those who did not have negative personal experiences with local women-reinforced the dominant narrative that local women were 'demanding,' have expectations that were too high, and desired material comforts that they could not afford. Half of our interviewees had been migrant workers, and they often credited the money they earned abroad as enabling their marriages. Several sought out commercial marriage brokers and married their wives within a few months of returning home. They argued that commercial matchmaking saved them time, which they did not have-if they were to court local women, it would take a few years, and there was no guarantee that the relationships would work out. Furthermore, many also said they were motivated by friends and relatives who had married Vietnamese women who turned out to be good wives.

Khei (43 years old, shoe factory van driver), and his friend Gan (42 years old, air-conditioner technician) live in the vicinity of Ipoh, a large town that used to be the centre of the tin mining industry. Like many others, they left school early to work. Many would have found work in the tin mining industry or related occupations, but tin mining declined and finally halted altogether in the 1980s. Khei and Gan both migrated overseas, working in Singapore shipyards for about a year or two before heading out to Japan where Gan worked for nine years, and Khei for 13 years. Singapore was a common work destination, where Malaysians could easily obtain a work permit if they found employment. But many also ended up for long periods in Japan, Taiwan, and the UK, where they bypassed immigration controls by entering on tourist visas and overstaying, a practice referred to as 'jumped 
airplane.' Seow (41-year-old welder, married to Kinh, 37 years old) had worked illegally in Japan for 12 years, fixing cargo containers in a Taiwanese company. He told us that working in Japan enabled him not only to send money home to his mother, a vegetable farm labourer, to raise his younger siblings, but also enabled him to eventually buy a house, renovate it, and plan for marriage. Immediately upon his return from Japan, he contacted a commercial matchmaker, selected Kinh, and got married. His reserve funds also allowed him to take a month off work to help his wife settle in. More philosophical than others, he explained:

When I came back, I had an objective. That was to run the 'race of life.' Running the race of life meant getting married, having children, having a peaceful and happy family. ... I made plans. I have bought my house and my car. I should have some savings, I can settle down now, so I came back.

These returned migrants saw themselves as self-made, having encountered hardship and risky migrations, and worked their way out of poverty. For them, marriage was 'just reward,' and tied to companionship and care. Most of our interviewees said that their primary reason for marriage was to have a companion, someone to take care of the housework, provide care for them, and sometimes, for elderly parents (although there were also many who live on their own). Most regarded having children as not important, and having sons even less so. Gan, for example, said:

I just thought maybe it's nice to have a companion, someone to take care of me if I fell ill. I wasn't bothered about having children or not having them. ... I had thought I wouldn't marry, but then what's the point of being on this earth, all by yourself? ... If I can have a kid, I won't care if it's a boy or girl. ... I just want to have a good meal when I come back from work and also want her to be good and responsible to my family. That's enough. She can take care of my mother when I'm not around.

The majority of the men interviewed were either running small businesses (e.g. family-owned coffee shops and restaurants) or skilled employees (e.g. plumbers, tile workers, painters), mostly in construction. The Vietnamese 
women who married into small business families usually ended up 'helping' in the businesses. A few of these husbands explicitly gave this as a primary motivation for seeking marriage through commercial matchmaking. Chang (38 years old), for example, owned and operated a photo shop. While at first he had not been keen on marriage as he saw it as an added burden, he decided, in the end, to get married as it would help his business:

[I] didn't have enough helpers. ... I have to handle [the shop] alone... from morning till night. The most important thing was to find a helper.

When asked how getting a wife would help in this matter, he replied, 'How to say this... through training her ... slowly training her.'

The aspiration for care and (re)productive labour is therefore an important element in these men's marital aims, and this is often expressed through the notion of companionship. Melody Lu's (2012) study also found that 'companionship for old-age' was cited by Taiwanese army veterans as the main motivation for marrying women from mainland China, with emotional and physical care explicitly mentioned. She ventures that sexual pleasure is implied, while, as in our study, procreation and family lineage are seldom given as motivations. While the men might desire to have children, this was usually not placed as a priority, and many said that this was not under their control.

\section{Marriage to Help Natal Family}

The 32 Vietnamese wives were from rural villages in southern Vietnam. Most of them were in their 20s when they married, and only seven were in their 30s. The majority were from poor families, with parents engaged in farming, raising livestock, breeding fish, or running small businesses. Many left school early to help their families earn a living, and some worked in places such as garment or shoe factories, or fish processing plants. In their narratives, the primary reason given for getting married and migrating abroad is to obtain monetary resources in order to help their families in Vietnam. They also hoped for a better life, often framed against the view that Vietnamese husbands were drunkards and wife-beaters, hence their dire prospects if they were to marry Vietnamese men at home. For some, 
marriage migration was an option considered alongside labour migration. Most labour migration brokers required upfront payments but not marriage brokers. In Phan's narrative, for example, being a 'wife' and a 'worker' were conflating logics. Phan, 25 years old, married Lai, 45 years old, an out-ofwork plumber three years ago, and they had a 15-month-old daughter. She explained to us:

I was under the impression that there would also be employment opportunities for me here in Malaysia. The agent too assured me that I would be able to find a job in Malaysia and I would be able to earn quite a good salary. So I made up my mind and came to Malaysia. However, in reality, I am unable to seek employment in Malaysia.

When probed further, she said, 'Well, I was thinking that maybe I could get married and look for a job too. ... I was more interested in finding a job and making some money for myself.'

A similar narrative was evident in Thi's (32-year-old garment factory worker) account of her marriage to Liew, a painter. Thi had intended to migrate for work overseas, mentioning Japan, but her aunt advised her to get married abroad instead. Her aunt's argument was that as a migrant worker, she would be 'very vulnerable and dependent on the boss, and if you get a very bad boss, there's nobody to protect you'; whereas if Thi chose marriage, 'your husband would love you and therefore he would be the one to protect you.' However, when she got married, she realised that her husband did not earn much, so she could not ask her husband for money to send home. Driven by the need to send remittances home to meet the needs of her natal family, she searched all over for paid work, and finally, was able to take in home-based sewing work from a garment factory. While the job paid very little, she felt that this was the best option available to her.

The women in our study were on social visit passes given to foreign spouses for periods of three months, six months, and then annually (none have managed to apply for permanent residency). While the social visit pass prohibits employment or engagement in business activities, this was rarely cited as a significant barrier to being employed. Small business families enfolded the Vietnamese spouses into their businesses as normative practice, even though this was against the law. ${ }^{9}$ Those who married into non-business 
families also found ways to work and earn money. For example, Dung (30 years old) found work as an hourly-paid domestic worker at a maid agency opposite the motor workshop where her husband Shin worked, while Anh (27 years old) worked for five months as a daily wage worker at a construction site that her husband was managing, telling us that, 'It was illegal, [but] somehow [I could work].'

As the women could be caught for working illegally, some expressed the aspiration to obtain permanent residency as this would allow them to work legally. However, most were more concerned with the immediate impediments, such as the limits of the local economy, their relative immobility, and the lack of access to financial capital. Phan, for example, who lived in a Chinese new village, ran a small business making local cakes and noodle dishes for distribution at food outlets three days a week. She wanted to do more, but there was insufficient demand for her wares. Likewise, Kinh, having established a family with two young children, wanted to go out to work, but her husband Seow explained that what Kinh could earn as a worker positioned at a low stratum within the economy would not make it worthwhile for the family, particularly given the (hidden) cost of childcare if this were to be commercially outsourced.

\section{Conflicts and Compromises}

Most of the couples in our study had not been married for long - the longest was for five years - with a median of two years and an average of 2.2 years. A few were married for less than a year when we met them. The couples were on average 18 years apart in age, with the age gap falling mainly between 10 to 25 years. The gender power balance was heavily weighted in the husbands' favour, given the advantage of age, patrilocality, income, and citizenship. The couples adhered to normative gender roles of husbands being earner-providers and wives' reproductive worker-carers. As Seow explained, his four-year-old marriage to Kinh was a happy one:

Oh honestly speaking, I am very contented marrying my wife. She manages the home very well. It's all peaceful and happy. She cleans the floor, washes the things and clothes. She also cooks rice and other dishes. I do the work outside and she takes care of the things at home. 
The discourse on housework drew on the underlying and perhaps unspoken agreement of what constituted the desired marital exchange, with conflicts arising when one spouse thought to have not kept to their side of the bargain. Khei (43 years old), married to a much younger Huong (23 years old), complained:

When we got married, I asked her what the man's and woman's roles are in the house. She agrees that the man goes out to work and the woman should keep the house. But sometimes she doesn't do the housework, so I have to tell her. She doesn't like it when I raise my voice, so I try to keep my voice down and tell her. ... Since she is married to me, she has to listen to me too ... I have to explain that she can't just have her way.

In contrast, Huong told us that her husband pampered her, and that he did everything for her such that she did not even have to cook or do much housework (they live on their own). Despite his unhappiness, Khei excused Huong for being 'too young and immature,' pledging anew to be patient with her. He also provided Huong with a small monthly allowance, which led Huong to consider him a generous husband willing to fund her remittances. Khei expressed to us his fear that Huong would run away. Despite the inherent asymmetry, the gender power balance appeared to be kept in check by the ever-present threat that the Vietnamese wives could run away. Both husbands and wives stressed in their narratives that husbands had to treat their wives well to prevent wives from running away. The 'runaway' narrative was usually linked to husbands not being able, or willing, to provide for their wives economically, although occasionally there were allusions to domestic violence.

While the couples in our study mainly adhered to normative gender roles, we found, nevertheless, many instances of husbands, and not only wives, performing care and intimate labour, an aspect overlooked in previous studies. First, there were many cases where husbands 'helped' their wives in performing housework and care work especially after childbirth and when babies were small. Lai (45 years old), for example, took care of his wife Phan (25 years old) after childbirth, such as cooking and washing her clothes. Chien (27 years old) told us that her husband would look after their new-born baby when he returned from work so that Chien could rest, and 
although Chien breastfed the baby, nevertheless, they took turns at night to tend to their son. Second, some husbands took pains to ensure their wives' well-being by enabling and encouraging their social connections with other Vietnamese wives. They would bring their wives to their friends' homes for visits and social get-togethers, make available their own homes, or take over childcare duties. For example, Low (58 years old), married three years ago to Khanh (34 years old), with an eight-month-old son, spent his weekends bringing Khanh to visit her friends, including outstation visits. He also sent Khanh together with their son back to Vietnam whenever she requested. Third, noting that the relations and practices of care and money are intertwined, we observe how relationships of money could also be relationships of intimacy. For example, Chien and her husband MK (49 years old) lived with MK's mother and sister. Chien found her in-laws difficult to handle, but her husband's love and support 'kept her life shining.' Chien told us that MK regularly sent money to help her family in Vietnam, but they kept this a secret as Chien would be treated badly if MK's mother found out. Intimate relationships grew out of both financial provision as well as shared knowledge between spouses that excluded third parties.

Although money is often used as a measure of care and love, its meaning lies in the context of the spousal relationship. Thus, the lack of money can be ameliorated within a relationship of love and trust, as we can see in the example of Hien. In conversation, Hien and her friend Lien sometimes joke that they are the most pitiful wives in their social group because their husbands are poor, but they would also say that 'it is alright to have a poor husband if the poor husband is a loving husband.' Hien, 34 years old, is married to Huan, 53 years old, and has given birth to a baby son. Early in the marriage, Huan went through a period during which he earned very little money and the family's budget was tight. Hien told us that Huan explained his situation to her, acknowledging that Hien was suffering together with him, reassuring her that the hardship was temporary, and hoping that Hien could endure it with him. Now that Huan was earning more regularly, and although money was still tight especially with the new-born baby, he had given her some money to send home. The little money that she received gained meaning within this relational context. In describing her husband to us, Hien said that he was kind, devoted to his family, generous, and willing to help her family in Vietnam.

In contrast to this case, the relationship between Nhu (29 years old) 
and Ting (39 years old) had all but broken down. Ting owned a shoe shop, and they worked together in the shop for 12 hours every day. Married for four years with a three-year-old son, Ting's complaints about Nhu were manifold - she slept late, went out frequently, did not do any houseworkbut central to his unhappiness was Nhu's constant asking for money to send home. Ting exclaimed, 'You know, she has nine brothers; why can't nine sons rear two parents? Why must I send them the money?' Nhu was constantly pressured by her mother to send money home. While she admitted that her husband had given her money to send home - sometimes RM1,000 (about USD300 in December 2009), other times RM2,000 - the crux of her dissatisfaction was that Ting did not give her a regular salary for working in the shop, only small ad-hoc amounts of pocket money. She had to ask and only recently did her husband give her a monthly allowance of RM300, which was less than the RM500 salary paid to the shop assistant that he employed. Furthermore, she compared herself to her sister-in-law, who was paid RM1,000 - more than three times Nhu's allowance-when she came to help out in the shop for a time. For Ting, the exchange relationship had broken down as Nhu had siphoned off too much money for her natal family, while for Nhu, the money she received from Ting as his wife was not comparable to her husband's contribution to others, including his employee and his sister.

Other than money and care, we observe that language and communication also have a relational aspect. While Vietnamese wives' limited proficiency in the language of the marital family could be a source of conflict, tension, or isolation (Kim, 2010), we found that it has obstructive significance only in cases of marital breakdown. Among the women we interviewed, we found a few already knew some Mandarin before they left Vietnam, but most picked up either Mandarin or Cantonese after marriage. The matchmakers would give the women a Vietnamese-Mandarin book and encouraged them to learn the language while they were waiting for a match. Thu (22 years old, married one and a half years with a three-month-old son) said:

After I've been here for a week, then I thought about using the book to tell my husband that it was very boring to stay home, [and] asked him to bring me over there to help out. ... [A]fter I've stayed here for around a month, I learnt how to speak [Cantonese]. I started going out with him to work every day, ... until I gave birth. 
Her husband Pang (42-year-old coffee shop owner-operator) recalled that at the beginning, '... can't really talk about anything that is too in-depth, just the normal things, you care for her and ask her if there's anything she wants and such ...'. Most couples, like Pang and Thu, said that they did have problems in the beginning, but the wives picked up the language quite quickly, with husbands playing their part in teaching them the language.

Nevertheless, the case of Michael and Ngon is an example where language and communication were cited as having contributed to marital breakdown. Michael (52 years old) married Ngon (36 years old) two years ago. Michael had a chicken rice stall and by his own admission, the primary motivation for him to marry Ngon was to have a helper for his business, as well as to take care of him as he grew old. Their marriage had irretrievably broken down, and for Michael, the main reason was that he felt cheated because he had only recently discovered that Ngon was a divorcee who had left her two children with her mother in Vietnam to come to Malaysia. In addition, he attributed the failure of their marriage to a language barrier. Although he observed that many Vietnamese were good at picking up the local language, his wife was 'poor in the language,' and 'a very slow learner.' Nevertheless, his narrative reveals that the difficulty in communication was also embedded in their marital relationship. He said:

At the moment the problem hasn't been overcome yet. ... If she doesn't have the initiative to learn ah, then there's no point to teach her.... Of course, it's my duty to talk to her, speak to her. But one thing is that, in our relationship, ... there's nothing for us to talk, you see. And she doesn't bother to ask me what is this, what is that. So in the long run, something happened in the relationship.

In her exchanges with us, Ngon never once cited language difficulties as the cause of their marital breakdown. Ngon complained to us that Michael treated her like a servant or work assistant, and did not love or care about her. The money that he gave her was less than what he paid his employeehelper, and when she requested money for her mother's medical expenses, he had turned her down. He had never bought her a single piece of clothing, and one time, when she requested him to buy her a skin-lightening cosmetic, his response was for her to use chicken fat to apply on her face. They never go on short trips or holidays, and even trips to the shopping mall were rare. 
During their fortnightly off-days, whenever she accompanied him, it would be to the coffee shop where he met his male friends, which she found boring. For Ngon, it was clear that the marital breakdown was due to the lack of care that she received from Michael. The incongruence in Michael's and Ngon's narratives gives support to our contention that whether language difficulty is easily overcome or becomes problematic depends on the relational context.

\section{State Policies, Men's Perspectives, Gender Negotiations}

Our Malaysian case study makes several contributions to the literature on cross-border marriage and family social reproduction in Southeast and East Asian countries. First, at the level of state policies, the Malaysian context of virtual state neglect provides a contrast to the East Asian countries where cross-border marriages are recognised and addressed by the state to varying extents as a family social reproductive strategy. In South Korea, the government has encouraged and actively managed marriage migration since its beginning in the early 1990s, and governmental policies provide support to marriage migrants in education, social security, and childcare, effectively socializing marriage migrants in childcare responsibilities (Kim, 2010; Kim and Kilkey, 2018). These policies may be understood within a social investment paradigm, 'structured to ensure that marriage migrants contribute to stabilising families' social reproductive functions throughout the life course of families' (Kim and Kilkey, 2018: 24). Likewise, the Taiwanese government recognises the role of female immigrant spouses in social reproduction, providing marriage migrants with resources and opportunities to live and work in the country (Tsay, 2015: 79; Chang, 2017). In spite of concerns regarding social integration and restrictions put in place to handle 'sham marriages' and trafficking allegations, both Taiwan and South Korea have policies that generally facilitate the integration of marriage migrants since they fill a gap in family social reproduction for certain segments of their populations. Unlike Taiwan and South Korea, there are no institutional efforts in Malaysia to facilitate marriage migration and support the social reproductive roles of immigrant spouses. In this regard, the Malaysian situation is more similar to Singapore. In both countries, marriage to citizens does not guarantee rights to residency, employment, or access to social services. Although restrictions on employment for marriage migrants to Singapore have been relaxed in recent years, nevertheless, rights to work, 
residency, and citizenship are still limited (Yeoh et al., 2021). In both these countries, the lack of state support for cross-border marriage migrants means that the responsibility for social reproduction remains within the family and private realms.

Second, our case study contributes to filling the gap in the literature on men's perspectives in cross-border marriages. With some exceptions that examine masculinities (Charsley, 2005; Suzuki, 2007; Cheng et al., 2014), current literature mostly derives from women's perspectives, focusing on their vulnerable position, citizenship issues, and everyday struggles with structural constraints, social norms, and family hierarchies (Chang, 2017; Kim 2010). From the husbands' narratives, we are able to draw out a significant strand of labour migration histories from the labour-sending Chinese Malaysian communities, reflecting the view that the Chinese Malaysian men who marry Vietnamese women are not uniformly rural, poor, lowly educated, and marginalised in the local marriage market, but also include self-made individuals with cosmopolitan outlooks honed by their migration experiences abroad in global cities and the global North. We have also highlighted husbands' performances of care and their attention to their wives' well-being by encouraging marriage migrants' social interactions and networks. Building a community of marriage migrants is important in providing a mutual support network in the absence of family and kinship support, and a lack of access to social services.

Finally, our study adds to the literature that provides a more nuanced understanding of women's motivations in marriage migration as not only limited to aspirations for economic security and upward geographical mobility, but also encompassing a desire for a 'better life,' that includes marriage with a kind husband, affection, children, and independent income from employment (Kim, 2010: 721). Nevertheless, by highlighting the juxtaposition of marriage migration and work migration options in women's narratives, we show that a primary consideration is to contribute to social reproduction for their natal family. Adding also to the literature on 'global spatial hypergamy,' where women from poorer countries migrate to more affluent countries through marriage (Constable, 2005), our study reinforces the prevalent view that these patrilocal cross-border marriages operate to perpetuate normative gendered power structures in families (Kim 2010: 718). This does not mean however those hierarchical gender roles are played rigidly according to tradition. We have underscored the importance 
of a relational context for understanding the meanings attached to money and care exchanges, reflecting dynamic processes of negotiations, conflicts, and compromises. As Jongwilaiwan and Thompson point out (2011: 363), '... under conditions of cross-cultural, transnational marriage migration, traditional cultural scripts of marriage and gender roles become more tenuous,' and '[t]he weight of negotiation falls more heavily on the actors themselves - on women and men as social agents seeking to optimise subjectively desired and differently imagined outcomes.'

\section{Conclusion}

In this paper, we have situated commercially-mediated cross-border marriages in relation to migration and social reproduction. Using the frame of social reproduction to examine care relationships within crossborder marriages, we are able to connect seemingly disparate migration trajectories, i.e. the labour migration of Chinese Malaysian men and the marriage migration of their Vietnamese spouses, across time and space. These different migration flows are usually analysed separately, but they are in fact interconnected, contributing to different configurations of social reproduction (Kofman, 2012).

It has been pointed out that transnational migration necessarily involves the reconfiguration of family and care relationships, and the reorganisation of the everyday practice of social reproduction (Locke et al., 2013). In our study, the labour migration of Chinese Malaysian men during their twenties and thirties reconfigures social reproduction temporally and spatially within the individual life course, leading to both the deferment as well as enablement of marriage. In this sense, social reproduction is temporally extended from young adulthood to middle age, and spatially across national borders.

Our study also shows that women may consider marriage migration in parallel with labour migration, as the motivation to embark on either can be similar, i.e. to secure better options to contribute to the social reproduction of their natal families. While labour migrants are usually restricted from permanent settlement, women who migrate for marriage can potentially gain more permanence in the destination country. Nevertheless, marriage migrants who marry into low socio-economic households may experience a similar precarity as low-waged labour migrants. For this reason, it has been posited 
that marriage migration should be treated more centrally in studies of global migration and development (Piper and Lee, 2016).

Finally, our paper makes a contribution to the literature on care relationships in cross-border marriages. It strengthens the case that exchanges of care, reproductive labour, and money within these marriages, even though commercially-mediated, are embedded in relational meanings. Although money is used as a measure of affection and love, the exchange is not one of simple equivalence, but has to be understood within the context of the care relationship. Hence, we point to the significance of recognizing that the care work that shapes and sustains marital relationships are bidirectional, reciprocal, and undertaken by husbands as much as wives. This does not imply negating previous findings that men who engage in cross-border marriages seek to preserve male privilege in the normative gender order. Rather, men as active agents can also be invested in softening the rough edges of commercially-mediated marriages and mitigating its inherent power imbalance.

\section{Acknowledgement}

The research project 'State Boundaries, Cultural Politics and Gender Negotiations in International Marriages in Singapore and Malaysia' was funded by the Singapore Ministry of Education Academic Research Fund [MOE AcRF Tier 2 Grant No T208A4103]. The Asia Research Institute rendered valuable infrastructural and administrative support. Professor Rashidah Shuib and the Women's Development Research Centre (KANITA) of the Universiti Sains Malaysia extended institutional sponsorship. We gratefully acknowledge the research work carried out by Vu Thi Kieu Dung, Tan Pok Suan, and Nguyen Thi Thanh Tam.

\section{Funding}

This work was supported by the National Population and Family Development Board, Malaysia (Grant No.: GA025-2021). 


\section{Notes}

1 Malays constituted $54.6 \%$ of the population, and with other indigenous groups, made up the Bumiputera category which constituted $67.4 \%$ (Department of Statistics Malaysia, 2011).

2 See for example 'Chinese may fall to the third spot soon,' The Star, 28 Feb 2016. Retrieved from: https://www.thestar.com.my/news/ nation/2016/02/28/chinese-may-fall-to-third-spot-soon-while-thedecline-in-the-percentage-of-chinese-population-is-an/ (Accessed 8 June 2021); 'Think tank predicts Chinese Malaysian population may drop below 20pc by 2030,' Malay Mail, 21 January 2017. Retrieved from: https://www.malaymail.com/news/malaysia/2017/01/21/thinktank-predicts-chinese-malaysian-population-may-drop-below-20pcby-203/1297791 (Accessed 8 June 2021).

3 'Cupid gets to work at MCA matchmaking party,' Malaysiakini, 13 August 2001. Retrieved from: https://www.malaysiakini.com/ news/4284 (Accessed 11 June 2021).

4 'More non-Malays marrying foreign women,' Bernama, 8 November 2006.

5 Personal communication with Tey Nai Peng. Analysis of the two percent sample of the 2010 Population and Housing Census shows that for every 10,000 male Chinese heads of household, 234 were married to foreign-born spouses. These were led by spouses born in Indonesia ( 75 per 10,000$)$, followed by Thailand (28 per 10,000), then the Philippines (21 per 10,000), China (20 per 10,000), and Vietnam (20 per 10,000).

6 These were set up in the 1950s by the British colonial government to resettle the rural Chinese population during the Communist insurgency.

7 Of the 37 husbands for whom we have information, 20 were in their $40 \mathrm{~s}, 10$ in their $30 \mathrm{~s}$, and seven in their $50 \mathrm{~s}$ at the time of marriage. Except for six divorcees and one widower, the others were all in their first marriages.

8 There were three of better means-one ran a 200 -acre oil palm 
plantation which his family owned, another was a businessman living in an upmarket part of town, while the third was a retiree with inherited wealth. The majority had schooling until the secondary level; only two had tertiary education, both overseas.

9 There have been occasional press reports of Vietnamese wives being caught for working in their husband's businesses. See for example, 'Immigration: Ng's Vietnamese wife on social visit pass caught working,' The Star, 2 April 2008. Retrieved from:https://www.thestar. com.my/news/nation/2008/04/02/immigration-ngs-vietnamese-wifeon-social-visit-pass-caught-working/ (Accessed 13 June 2021).

\section{References}

Bélanger, D. (2010). Marriages with foreign women in East Asia: bride trafficking or voluntary migration? Population and Societies, 469, 1-4

Chang, H-C. (2017). A two-step social integration model for transnational marriage migrants in Taiwan and South Korea: "Marital family first, host society second." In Fresnoza-Flot, Asuncion and Gwénola Ricordeau (eds), International Marriages and Marital Citizenship: Southeast Asian Women on the Move (pp. 176-195). London: Routledge.

Charsley, K. (2005). Unhappy husbands: Masculinity and migration in transnational Pakistani marriages. The Journal of the Royal Anthropological Institute, 11(1), 85-105.

Chee, H L, Yeoh, B.S.A., \& Vu, T.K.D. (2012). From client to matchmaker: Social capital in the making of commercial matchmaking agents in Malaysia. Pacific Affairs, 85(1), 91-115. DOI:10.5509/201285191

Cheng, I. (2013). Making foreign women the mother of our nation: the exclusion and assimilation of immigrant women in Taiwan. Asian Ethnicity, 14(2), 157-179. DOI: 10.1080/14631369.2012.759749

Cheng, Y, Yeoh, B.S.A., \& Zhang, J. (2015). Still 'breadwinners' and 'providers': Singaporean husbands, money and masculinity in transnational marriages. Gender, Place and Culture, 22(6), 867-883. DOI: 10.1080/0966369X.2014.917282

Constable, N. (2005). Cross-Border Marriages: Gender and Mobility in Transnational Asia. Philadelphia: University of Pennsylvania Press. 
Department of Statistics Malaysia. (2011). Population Distribution and Basic Demographic Characteristic Report 2010. (Updated: 05/08/2011). Retrieved from: https://www.dosm.gov.my/v1/index.php?r=column/ ctheme\&menu_id=L0pheU43NWJwRWVSZk1WdzQ4TlhUUT09\&b ul_id=MDMxdHZjWTk1SjFzTzNkRXYzcVZjdz09.

Department of Statistics Malaysia. (2016). Population Projection (Revised), Malaysia, 2010-2040, Press Release, 4 November. Retrieved from: https://www.dosm.gov.my/v1/index.php?r=column/ctheme\&menu_id= L0pheU43NWJwRWVSZklWdzQ4TlhUUT09\&bul_id=Y3kwU2tSNV FDOWp1YmtZYnhUeVBEdz09\#

Douglass, M. (2006). Global householding in Pacific Asia. International Development Planning Review, 28(4), 421-46. DOI: 10.3828/idpr.28.4.1. Hochschild, A.R. (2000). Global care chains and emotional surplus value. In Hutton, W. and A. Giddens (eds), On the Edge: Living with Global Capitalism, (pp. 130-46). London: Jonathan Cape.

Isaksen, LW, Devi, SU, \& Hochschild, AR. (2008). Global care crisis: A problem of capital, care chain, or commons? American Behavioral Scientist, 52(3), 405-425. DOI: 10.1177/0002764208323513

Jones, G.W., Hull, T.H., \& Mohamad, M. (2011). Marriage trends in insular Southeast Asia: their economic and socio-cultural dimension. In Jones, Gavin W., Terence H. Hull, and Maznah Mohamad (eds), Changing Marriage Patterns in Southeast Asia: Economic and Socio-cultural Dimensions (pp. 1-10). London: Routledge.

Jones, G.W. (2012). International marriage in Asia: What do we know, and what do we need to know? In Kim, Doo-Sub (ed.) Cross-Border Marriage: Global Trends and Diversity (pp. 13-49), Seoul: Korea Institute for Health and Social Affairs.

Jongwilaiwan, R., \& Thompson, E.C. (2013). Thai wives in Singapore and transnational patriarchy. Gender, Place and Culture, 20(3), 363-81. DOI: 10.1080/0966369X.2011.624588

Kim, G., \& Kilkey, M. (2018). Marriage migration policy in South Korea: Social investment beyond the nation State. International Migration, 56(1), 23-38. DOI: 10.1111/imig. 12350

Kim, M.K. (2010). Gender and international marriage migration. Sociology Compass, 4(9), 718-731. DOI: 10.1111/j.1751-9020.2010.00314.x 
Kofman, E. (2012). Rethinking care through social reproduction: articulating circuits of migration. Social Politics, 19(1), 142-162. DOI:10.1093/sp/ jxr030

Koh, S.Y. (2014). How and why race matters: Malaysian-Chinese transnational migrants interpreting and practising Bumiputeradifferentiated citizenship. Journal of Ethnic and Migration Studies, 41(3), 531-550. DOI: 10.1080/1369183X.2014.937327

Lan, P-C. (2008). New global politics of reproductive labor: Gendered labor and marriage migration. Sociology Compass, 2(6), 1801-1815. DOI: 10.1111/j.1751-9020.2008.00176.x

Laslett, B., \& Brenner, J. (1989). Gender and social reproduction: Historical perspectives. Annual Review of Sociology, 15, 381-404.

Lee, H. (2012). Political economy of cross-border marriage: Economic development and social reproduction in Korea. Feminist Economics, 18(2), 177-200. DOI: 10.1080/13545701.2012.688139

Locke, C., Seeley, J., \& Rao, N. (2013). Migration, reconfigurations of family relations and social (in)security: An introduction. Third World Quarterly, 34(10), 1872-1880. DOI: 10.1080/01436597.2013.851933

Lu, M. C-W. (2012). Transnational marriages as a strategy of care exchange: veteran soldiers and their mainland Chinese spouses in Taiwan. Global Networks, 12(2), 233-251. DOI: 10.1111/j.1471-0374.2012.00349.x

Piper, N., \& Lee, S. (2016). Marriage migration, migrant precarity, and social reproduction in Asia: an overview. Critical Asian Studies, 48(4), 473-493. DOI: 10.1080/14672715.2016.1226598

Suzuki, N. (2007). Marrying a Marilyn of the tropics: Manhood and nationhood in Filipina-Japanese marriages. Anthropological Quarterly, 80(2), 427-454. DOI: 10.1353/anq.2007.0035

Tey, N.P. (2011). Understanding marriage and divorce trends in Peninsular Malaysia. In Jones, Gavin W., Terence H. Hull, and Maznah Mohamad (eds), Changing Marriage Patterns in Southeast Asia: Economic and Socio-cultural Dimensions (pp. 137-155). London: Routledge.

Tsay, C-1. (2015). Migration between Southeast Asia and Taiwan: Trends, characteristics and implications. Journal of ASEAN Studies, 3(2), 68-92. DOI: $10.21512 /$ jas.v3i2.842

Winders, J., \& Smith, B.E. (2018). Social reproduction and capitalist production: A genealogy of dominant imaginaries. Progress in Human Geography, 43(5): 871-889. DOI: 10.1177/0309132518791730 
Yeates, N. (2004). Global care chains. International Feminist Journal of Politics, 6(3), 369-391. DOI: 10.1080/1461674042000235573

Yeoh, B.S.A., Chee, H.L., Anant, R., \& Lam, T. (2021). Transnational marriage migration and the negotiation of precarious pathways beyond partial citizenship in Singapore. Citizenship Studies, 1-20. DOI: 10.1080/13621025.2021.1968681

Yeoh, B.S.A., Chee, H.L., \& Vu, T.K.D. (2014). Global householding and the negotiation of intimate labour in commercially-matched international marriages between Vietnamese women and Singaporean men. Geoforum, 51, 284-293. DOI: 10.1016/j.geoforum.2013.09.012

Yeoh, B.S.A., Chee, H.L., \& Baey, G.H.Y. (2013). The place of Vietnamese marriage migrants in Singapore: social reproduction, social 'problems' and social protection. Third World Quarterly, 34(10), 1927-1941, DOI: 10.1080/01436597.2013.851959 